\title{
The Views of Turkish Science Teachers about Gender Equity within Science Education
}

\author{
Şahin İdin*, İsmail Dönmez \\ Ministry of National Education, Turkey \\ *Corresponding Author: sahinidin@hotmail.com
}

\section{ABSTRACT}

The aim of this study was to investigate Turkish Science teachers' views about gender equity in the scope of science education. This study was conducted with the quantitative methodology. Within this scope, a 35-item 5-point Likert scale survey was developed to determine Science teachers' views concerning gender equity issues. 160 Turkish Science teachers completed the survey. Their responses were analyzed using SPSS. It was revealed that many Turkish Science teachers did not think there was any gender equity in Science Teaching Programmes or their Science textbooks. These Science teachers' views also indicated that there were no gender policies in Turkish science education. They believed gender equity issues were important for students' science achievement. It is recommended that Science teachers have some in-service training on gender equity.

KEY WORDS: gender equity; science education; science teacher; science; quantitative methodology

\section{INTRODUCTION}

I $n$ recent years, there have been changes to the structure of the science curriculum in Turkey. In 2000, comprehensive changes were made to the science curriculum by the Ministry of National Education (MEB) (2000). It was emphasized that students would be more active during the science learning process. In 2005, another change was carried out to the science curriculum. The name was changed to "science and technology" and the "constructivist learning approach" was mandated for conducting science courses. In 2013, a third change was applied, and the "inquiry based learning" approach was implemented as the basic teaching approach for the science curriculum, and the name of the course was changed to "science course" (MEB, 2015a). In 2017, MEB published a draft science program for Grades 3-8 and had sought to obtain opinions on it from Turkish science educators. It is thought that this new program is going to be used in 2018. It is anticipated that new learning and teaching approaches will be used such as STEM education (MEB, 2017). All these changes have been carried out in terms of having more quality science courses and to provide all students with equal access to science education.

Therefore to understand gender equity, it is necessary to identify it. According to UNESCO (2000), gender equity means fairness of treatment for both women and men, according to their respective needs. This may include equal treatment or treatment that is different but which is considered equivalent in terms of rights, benefits, obligations, and opportunities. Magno and Silova (2007) argued that regardless of sex differences, gender equity was warranted within educational outcomes.
There have been many studies carrying out related to gender equity in education to include gender based studies in science education. These studies investigated a range of gender-related topics such as gender-biased messages in Science textbooks, stereotypical gender images in science textbooks, gendered science curricula, and career guidances. It is known that in some examples within scientific experiments, men are more put than women. Bazler (1991) compared two editions (1970 and 1973) of seven high school chemistry texts written by different authors and analyzed them for gender fairness. Potter and Rosser (1992) examined five widely used $7^{\text {th }}$ grade life Science textbooks, and they investigated then looking for sexist language, images, activities, and curricular content. Zittleman and Sadker (1996) investigated the treatment of gender in 23 teacher education textbooks which were published between 1998 and 2001. They stated in their study, although most texts included some coverage of gender, it was seen that the coverage was minimal and not always positive. Dimopoulos et al. (2005) presented an analyses of the way language was employed in Greek physics, chemistry, and biology textbooks to project negative gendered messages. Similarly, Whiteley (2007) in his study, analyzed Science textbooks used in the lower forms of secondary schools in Jamaica a highlighted their lack of gender fairness. Lee and Collins (2009) reported on the extent of gender stereotyping in terms of linguistic and pictorial messages in 10 Australian English-language textbooks. Finally, Good et al. (2010) investigated the effect of gender stereotypic and counterstereotypic images on female and male high students' science comprehension and anxiety.

\section{Aim and Significance of the Study}

Studies have been found which are related to gender based issues; however, a search of this literature highlights that there 
have not been any studies conducted with Turkish middle school Science teachers about gender equity. As such, this is the first study that has been carried out with middle school Science teachers in Turkey and gender equity. To explore Science teachers' views on gender equity is important as in Turkey it is aimed to provide all students with quality science. The science curriculum and other educational documents claim that they provide gender equity within education for all students. Therefore, Science teachers have a significant role as they conduct the science teaching process. As a result, this study is a very important area of the research. The research question of this study was "what are the views of Science teachers on gender equity and its issues within the scope of gender equity."

\section{METHODS}

This section discusses the research methodology, the study group, the data collection tools and the application of data collection tools, processing and analysis of the data.

\section{Research Model}

The quantitative methodology of survey instruments was chosen to address the study's research question. The descriptive model was used from the quantitative research methods. The choice of the descriptive model is based on the views of participants on a causal basis, or on the attitudes, skills, and attitudes (Fraenkel and Wallen, 2011).

\section{Participants of the Study}

Participants of the study were middle school science teachers who were working in various regions of Turkey in the academic year of 2015-2016. 160 middle school Science teachers responded to the survey. Most of the participants were provided to fill in the survey by Google forms. The other participants were carried out to fill in the survey through face to face meetings. To ensure ethics of the study, there were taken a supervisor's advice, who has expertise in the field of ethics. Within this scope, all participants voluntarily joined the study. "Volunteer participation forms" were prepared to approve that the Science teachers participated in the research voluntarily, and approvals of the teachers were received. The reason for carrying out this study was explained to all the participating teachers. They were informed about the aim of the study and how the data would be used. It was explicitly stated that their personal information would not be shared with anyone and only their anonymous responses would be used in any possible reporting of this study. These participants worked in three different middle school types: Public (101 teachers), public religious (39 teachers), and private (20 teachers). 73 (45.6\%) female and $87(54.4 \%)$ male science teachers participated the study. 147 (91.9\%) teachers have a degree, $12(7.5 \%)$ a master's degree, and $1(0.6 \%)$ a $\mathrm{PhD}$ degree. The participants came from Turkey's seven different regions: Marmara region - 36 teachers, Ege region - 21, Akdeniz region - 16, Doğu Anadolu region - 14, Karadeniz region - 15, İç Anadolu region - 44, and Güneydoğu Anadolu region - 14. In addition, participants tenure as a science teacher ranged from new teachers to experienced teachers: $1-5$ years as a teacher - 43 teachers, 6-10 years - 43, 11-15 years - 39, 16-20 years - 26, 21-25 years -5 , and 4 teachers reported more than 26 years of teaching.

\section{Data Collection Tool}

A 35-item 5-point Likert scale survey was developed to determine Science teachers' views about the gender equity in science education. First, "gender equity" based surveys were investigated to determine what statements they had. Then, related studies were found, and their content was investigated. From this analysis of statements, the study's gender equity in the science education survey was created. The survey's 5-point Likert-type scale ranged from strongly agree, agree, irresolute, disagree, and to strongly disagree. For this study, the survey analysis focused on six dimensions: Science curriculum, Science textbooks, Science Teaching Programme, science achievement, gender policy in science education, and images in Science textbooks (Appendix 1). The data reported in this study was obtained using the 11 statements below. These statements were selected as they were indicators of the participating teachers' views on gender equity.

- There is gender equity in education in Turkey

- There is gender equality in science education in our country

- Science curriculum has been prepared by considering gender equity

- Images in Science textbooks have been made by considering gender equity

- Career guidance is prepared by considering gender equity

- Science teaching which has been conducted in schools has strengthened gender inequity stereotype

- Boys and girls are exposed to gender inequality at the same ratio

- Gender inequality has effect on the scores obtained in the exams

- There is the contribution of gender inequality to differences in the dropout rate of girls and boys

- Gender inequality has effect repetition rate in boys and girls

- Girls are more successful in science lessons and classroom or extracurricular, therefore, more time should be allocated for boys than for girls.

\section{Data Collection Process}

The measurement tool was prepared and physically distributed to 110 participants. Participants were informed the survey should take approximately 20-30 min to complete. In addition, the survey was administered using Google Doc form to reach Science teachers who were not able to attend a National Conference held in Ankara in September 2015. As a result, another 50 participants completed the survey via Google Doc form.

\section{Data Analyses}

In the study, the 11 items were analyzed using Social Package for Social Sciences (22.0). The data were analyzed using 
frequency counts and percentage values and are shown in Tables 1-11. Frequency and percentage values have been given for each statement.

\section{Validity and Reliability and Ethics of the Study}

To provide validity of the measurement tool, the survey instrument was critiqued by two experts, one of them expertness is in science education, and other one's expertness is in measurement and evaluation. As a result of their advice, two items were removed. Then, two Science teachers and two Turkish teachers examined the instrument to determinate if it contained any unfamiliar language negatively impacting on

\begin{tabular}{|c|c|c|c|c|c|}
\hline Gender & $\begin{array}{l}\text { Strongly } \\
\text { disagree }\end{array}$ & Disagree & Irresolute & I agree & $\begin{array}{c}\text { Strongly } \\
\text { I agree }\end{array}$ \\
\hline \multicolumn{6}{|l|}{ Female } \\
\hline F (\%) & $16(21.9)$ & $24(32.9)$ & $5(6.8)$ & $15(20.5)$ & $13(17.8)$ \\
\hline \multicolumn{6}{|l|}{ Male } \\
\hline $\mathrm{F}(\%)$ & $19(21.8)$ & $26(23)$ & $10(11.5)$ & $20(29.9)$ & $12(13.8)$ \\
\hline \multicolumn{6}{|l|}{ Total } \\
\hline $\mathrm{F}(\%)$ & $35(21.8)$ & $50(31.2)$ & $15(9.3)$ & $35(21.8)$ & 25 (15.6) \\
\hline
\end{tabular}

\begin{tabular}{lccccc}
\hline $\begin{array}{l}\text { Table 2: Gender equity in science education in our } \\
\text { country }\end{array}$ \\
\hline Gender & $\begin{array}{c}\text { Strongly } \\
\text { disagree }\end{array}$ & Disagree & Irresolute & I agree & $\begin{array}{c}\text { Strongly } \\
\text { I agree }\end{array}$ \\
\hline $\begin{array}{c}\text { Female } \\
\text { F (\%) }\end{array}$ & $11(15.1)$ & $28(38.8)$ & $10(13.7)$ & $17(23.3)$ & $7(9.6)$ \\
$\begin{array}{c}\text { Male } \\
\text { F (\%) }\end{array}$ & $10(11.5)$ & $12(13.8)$ & $8(9.2)$ & $33(37.9)$ & $24(27.6)$ \\
$\begin{array}{c}\text { Total } \\
\text { F (\%) }\end{array}$ & $21(13.1)$ & $40(25)$ & $18(11.2)$ & $50(31.2)$ & $31(19.3)$ \\
\hline
\end{tabular}

\begin{tabular}{cccccc}
\hline \multicolumn{5}{c}{ Table 3: Science curriculum has gender equality } \\
\hline Gender & $\begin{array}{c}\text { Strongly } \\
\text { disagree }\end{array}$ & Disagree & Irresolute & I agree & $\begin{array}{c}\text { Strongly } \\
\text { I agree }\end{array}$ \\
\hline $\begin{array}{c}\text { Female } \\
\text { F (\%) }\end{array}$ & $9(12.3)$ & $33(45.2)$ & $24(32.9)$ & $4(5.5)$ & $3(4.1)$ \\
$\begin{array}{c}\text { Male } \\
\text { F (\%) }\end{array}$ & $7(8)$ & $38(43.7)$ & $23(26.4)$ & $16(18.4)$ & $3(3.4)$ \\
$\begin{array}{c}\text { Total } \\
\text { F (\%) }\end{array}$ & $16(10)$ & $71(44.3)$ & $47(29.3)$ & $20(12.5)$ & $6(3.7)$ \\
\hline
\end{tabular}

Table 4: Images consider gender equity

\begin{tabular}{cccccc}
\hline Gender & $\begin{array}{c}\text { Strongly } \\
\text { disagree }\end{array}$ & Disagree & Irresolute & I agree & $\begin{array}{c}\text { Strongly } \\
\text { I agree }\end{array}$ \\
\hline $\begin{array}{r}\text { Female } \\
\text { F (\%) }\end{array}$ & $9(12.3)$ & $33(45.2)$ & $23(31.5)$ & $6(8.2)$ & $2(2.7)$ \\
$\begin{array}{c}\text { Male } \\
\text { F (\%) }\end{array}$ & $8(9.2)$ & $39(44.8)$ & $20(23)$ & $16(18.4)$ & $0(4.6)$ \\
$\begin{array}{c}\text { Total } \\
\text { F }(\%)\end{array}$ & $17(10.6)$ & $72(45)$ & $43(26.8)$ & $22(13.7)$ & $2(1.2)$ \\
\hline
\end{tabular}

their understanding. Then, the survey was administered to a group of 20 Science teachers as a pilot study. This resulted in the study's 35 item survey instrument.

\section{RESULTS}

The participants were asked "there is gender equity in education in Turkey." The results are given in Table 1.

Many of the female teachers did not agree (16 - strongly disagree; 24 - disagree) that there was gender equity in education in Turkey. Although many of them thought that there was not any equity in the Turkish education, 15 of them

\begin{tabular}{llllll}
\hline \multicolumn{6}{l}{ Table 5: Career guidance and gender equity } \\
\hline Gender & $\begin{array}{c}\text { Strongly } \\
\text { disagree }\end{array}$ & Disagree & Irresolute & I agree & $\begin{array}{c}\text { Strongly } \\
\text { I agree }\end{array}$ \\
\hline $\begin{array}{c}\text { Female } \\
\text { F (\%) }\end{array}$ & $5(6.8)$ & $32(43.8)$ & $20(27.4)$ & $12(16.4)$ & $4(5.5)$ \\
$\begin{array}{c}\text { Male } \\
\text { F (\%) }\end{array}$ & $11(12.6)$ & $26(29.9)$ & $30(34.5)$ & $15(17.2)$ & $5(5.7)$ \\
$\begin{array}{c}\text { Total } \\
\text { F (\%) }\end{array}$ & $16(10)$ & $58(36.2)$ & $50(31.2)$ & $27(16.8)$ & $9(5.6)$ \\
\hline
\end{tabular}

\begin{tabular}{cccccc}
\hline Table 6: Science teaching strengthened gender inequity \\
\hline Gender & $\begin{array}{c}\text { Strongly } \\
\text { disagree }\end{array}$ & Disagree & Irresolute & I agree & $\begin{array}{c}\text { Strongly } \\
\text { I agree }\end{array}$ \\
\hline $\begin{array}{r}\text { Female } \\
\text { F (\%) }\end{array}$ & $5(6.9)$ & $10(13.9)$ & $28(38.9)$ & $17(23.6)$ & $12(16.7)$ \\
$\begin{array}{c}\text { Male } \\
\text { F (\%) }\end{array}$ & $3(3.4)$ & $12(13.8)$ & $33(37.9)$ & $27(31.0)$ & $12(13.8)$ \\
$\begin{array}{c}\text { Total } \\
\text { F (\%) }\end{array}$ & $8(5)$ & $22(13.7)$ & $61(38.1)$ & $44(27.5)$ & $24(15)$ \\
\hline
\end{tabular}

\begin{tabular}{llllll}
\hline \multicolumn{6}{c}{ Table 7: Boys and girls exposed to gender inequality } \\
\hline Gender & $\begin{array}{c}\text { Strongly } \\
\text { disagree }\end{array}$ & Disagree & Irresolute & I agree & $\begin{array}{c}\text { Strongly } \\
\text { I agree }\end{array}$ \\
\hline $\begin{array}{c}\text { Female } \\
\text { F (\%) }\end{array}$ & $12(16.4)$ & $18(24.7)$ & $18(24.7)$ & $19(26.0)$ & $6(8.2)$ \\
$\begin{array}{c}\text { Male } \\
\text { F (\%) }\end{array}$ & $12(13.8)$ & $21(24.1)$ & $22(25.3)$ & $27(31.0)$ & $5(5.7)$ \\
$\begin{array}{c}\text { Total } \\
\text { F (\%) }\end{array}$ & $24(15)$ & $39(24.3)$ & $40(25)$ & $46(28.7)$ & $11(6.8)$ \\
\hline
\end{tabular}

Table 8: Gender inequality effects exam scores

\begin{tabular}{cccccc}
\hline Gender & $\begin{array}{c}\text { Strongly } \\
\text { disagree }\end{array}$ & Disagree & Irresolute & I agree & $\begin{array}{c}\text { Strongly } \\
\text { I agree }\end{array}$ \\
\hline $\begin{array}{c}\text { Female } \\
\text { F }(\%)\end{array}$ & $7(9.6)$ & $21(28.8)$ & $25(34.2)$ & $15(20.5)$ & $5(6.8)$ \\
$\begin{array}{c}\text { Male } \\
\text { F }(\%)\end{array}$ & $15(17.2)$ & $33(37.9)$ & $30(34.5)$ & $9(10.3)$ & $0(0)$ \\
Total & & & & & \\
F (\%) & $22(13.7)$ & $54(33.7)$ & $55(34.3)$ & $24(15)$ & $5(3.1)$ \\
\hline
\end{tabular}




\begin{tabular}{|c|c|c|c|c|c|}
\hline Gender & $\begin{array}{l}\text { Strongly } \\
\text { disagree }\end{array}$ & Disagree & Irresolute & I agree & $\begin{array}{c}\text { Strongly } \\
\text { I agree }\end{array}$ \\
\hline \multicolumn{6}{|l|}{ Female } \\
\hline F (\%) & $6(8.2)$ & 14 (19.2) & $20(27.4)$ & $21(28.8)$ & $12(16.4)$ \\
\hline \multicolumn{6}{|l|}{ Male } \\
\hline F (\%) & $8(9.2)$ & $20(23.0)$ & $20(23.0)$ & $26(29.9)$ & $13(14.9)$ \\
\hline \multicolumn{6}{|l|}{ Total } \\
\hline F (\%) & $14(8.7)$ & $34(21.2)$ & $40(25)$ & $47(29.3)$ & 25 (15.6) \\
\hline
\end{tabular}

\begin{tabular}{llllll}
\hline $\begin{array}{l}\text { Table 10: Gender inequality effects repetition rate of boys } \\
\text { and girls }\end{array}$ \\
\begin{tabular}{llllll} 
Gender & $\begin{array}{l}\text { Strongly } \\
\text { disagree }\end{array}$ & Disagree & Irresolute & I agree & $\begin{array}{c}\text { Strongly } \\
\text { I agree }\end{array}$ \\
\hline $\begin{array}{c}\text { Female } \\
\text { F (\%) }\end{array}$ & $5(6.8)$ & $19(26.0)$ & $28(38.4)$ & $15(20.5)$ & $6(8.2)$ \\
$\begin{array}{c}\text { Male } \\
\text { F (\%) }\end{array}$ & $10(11.5)$ & $27(31.0)$ & $35(40.2)$ & $11(12.6)$ & $4(4.2)$ \\
$\begin{array}{c}\text { Total } \\
\text { F (\%) }\end{array}$ & $15(9.3)$ & $46(28.7)$ & $63(39.3)$ & $26(16.2)$ & $10(6.2)$ \\
\hline
\end{tabular} & & & & &
\end{tabular}

\section{Table 11: Girls are more successful so more time for} boys than girls needed

\begin{tabular}{cccccc}
\hline Gender & $\begin{array}{c}\text { Strongly } \\
\text { disagree }\end{array}$ & Disagree & Irresolute & I agree & $\begin{array}{c}\text { Strongly } \\
\text { I agree }\end{array}$ \\
\hline $\begin{array}{r}\text { Female } \\
\text { F }(\%)\end{array}$ & $15(20.5)$ & $19(26.0)$ & $25(34.2)$ & $14(19.2)$ & $0(0)$ \\
$\begin{array}{c}\text { Male } \\
\text { F }(\%)\end{array}$ & $16(18.4)$ & $24(27.6)$ & $30(34.5)$ & $14(16.1)$ & $3(3.4)$ \\
Total & & & & & \\
F $(\%)$ & $31(19.3)$ & $43(26.8)$ & $55(34.3)$ & $28(17.5)$ & $3(1.8)$ \\
\hline
\end{tabular}

stated "yes" there was. It should be noted that almost as many male teachers as female thought there was not any equity (20 - disagree; 19 - strongly disagree) within gender issues in education in Turkey.

The participants were asked that "there is gender equality in science education in our country." The results are given in Table 2.

Almost as many female teachers did not agree (11 - strongly disagree; 28 - disagree) that there was not any gender equity in science education in Turkey as for gender equity in Turkey. Similarly, while many of them thought that there was not any gender equity in science education in Turkey, $20.5 \%$ of them stated "yes" there was. We see that not as many male teachers think there was not any equity (10 - strongly disagree; 12 - disagree) within gender issues as they did for gender equity in science education.

The participants were asked that "science curriculum has been prepared by considering the gender equality." The results are given in Table 3.
We argue that science curricula are very important indicators and as such, they effect gender equity. Science teachers implement the science curriculum in their schools. Therefore, it is important to know Science teachers' views whether gender issues are considered by the science curriculum used in the scope of science education. In Table 3, it was seen that more male teachers ( $45=7$ - strongly disagree; 38 - disagree) than female teachers ( $42=9$ - strongly disagree; 33 - disagree) did not agree with this statement. Another interesting result within this statement was 24 female, and 23 male teachers were irresolute. It can be thought that these teachers either did not know the science curriculum or they did not know exactly what gender equity within science education involved.

The participants were asked that "images in the Science textbooks have been made by considering gender equity." The results are given in Table 4.

Images in textbooks are important indicators which give us an opportunity to be able to understand how gender equity is portrayed. 42 (33 - disagree; 9 - strongly disagree) female teachers thought that gender equity was not a consideration in Science textbooks. It was also seen more male teachers (8 - strongly disagree; 39 - disagree) thought the same. Interestingly, no male teachers thought gender equity was a consideration in Science textbooks.

The participants were asked that "career guidance is prepared by considering gender equity." The results are given in Table 5 .

Career guidance is an another important indicator of how gender equity is viewed in science education. 20 female and 30 male teachers did not hold any view on this question. It means nearly one-third (31.15\%) of these teachers are irresolute. 37 female teachers (5 - strongly disagree and 32 - disagree) and 37 male teachers (11 - strongly disagree, 26 - disagree) did not think career guidance was prepared to consider gender issues. It also means $46.25 \%$ of teachers did not think career guidance was prepared to consider gender roles.

The participants were asked that "Science teaching which has been conducted in schools has strengthened gender inequity stereotype." The results are given in Table 6 .

Table 6 highlights that 61 teachers think that Science teaching that is conducted in schools has been strengthened gender inequity. This result also highlights how $38.13 \%$ of these teachers stated their responses as 'Irresolute'. It can be understood that these teachers are not aware of gender equity and its issues or do not have enough knowledge on it. Besides this, 29 (17 - I agree; 12 - strongly I agree) female teachers and 39 (27 - I agree; 12 - strongly I agree) male teachers were in agreement with the statement. Therefore, they think the current Science teaching in schools strengthens gender inequity.

The participants were asked that "boys and girls are exposed to gender inequality at the same ratio." The results are given in Table 7. 
Many of both the female and male teachers think similarly on this question. This result means these teachers did not think that boys and girls were exposed to gender inequality in the same ratio. Although this result indicates that 25 female teachers (19 - I agree; 6 - disagree) and 32 male teachers (27- I agree; 5 - disagree) think boys and girls were exposed to gender equality in the same ratio. However, $25 \%$ of the teachers had no thoughts or did not want to respond to this question. Therefore, 63 teachers did not agree that boys and girls were exposed to gender issues while 57 of teachers think boys and girls were exposed to gender equity.

The participants were asked that "gender inequality has effect on the scores obtained in the exams." The results are given in Table 8.

This question was asked to Science teachers to investigate how Science teachers view if gender inequity affects boys' and girls' science scores. Many of female and male teachers think that gender inequity did not affect students' scores. It is interesting that 25 female and 30 male teachers did not indicate any view on this question.

The participants were asked that "there is contribution of gender inequality to differences in the dropout rate of girls and boys." The results are given in Table 9.

This question was asked to determine if Science teachers believed if the dropout rate is affected by gender inequity. It is seen that 21 female and 26 male teachers stated "I agree" on the survey - meaning they think gender inequity affected the dropout rate of students. 12 of female teachers stated "strongly agree" and as did 13 male teachers indicating they did think gender inequity strongly affected the rate of dropout between girls and boys. There was another interesting result within this question as 40 teachers stated their views as "irresolute" on this question.

The participants were asked that "gender inequality has effect repetition rate in boys and girls." The results are given in Table 10.

The repetition at the same grade due to gender inequality was asked to Science teachers. It has been found that most of the female teachers (28) have the "irresolute" view which was the same answer given by most male teachers (35). This result looks interesting since most teachers (both male and female) have no view on this statement. We expected that Science teachers would have some thoughts on the statement since they were current teachers at their schools but it is seen from the table that $39.37 \%$ of teachers did not state any view.

The participants were asked that "girls are more successful in science lessons and classroom or extracurricular, therefore, more time should be allocated for boys than for girls." The results are given in Table 11 .

This question tried to understand what views Science teachers think about the success of their students in terms of their gender. Many teachers did not think that "gender" had any effect on success. Many of the female teachers (20.5\% - strongly disagree; $26.0 \%$ - disagree) and male teachers (18.4\% - strongly disagree; $27.6 \%$ - disagree) did not think that gender affected students' science achievement. It is seen in Table 11, however, $19.2 \%$ of female teachers and $16.1 \%$ of male teachers did think that gender had a significant effect on students' Science achievement.

\section{DISCUSSION}

The Science curriculum is an indicator and provides information on gender equity within Science education. Science textbooks, Science activities, images, the role of boys and girls can be seen as tools in the science curricula. These tools are significant indicators as they help us to understand if there is gender equity in science education or not. Most of the female (12.3\% - strongly disagree; $45.2 \%$ - disagree) and most of the male teachers $(8.0 \%$ - strongly disagree; $43.7 \%$ - disagree $)$ did not think that the Turkish science curriculum had been prepared considering gender equity.

As authors, we wanted to learn what views Science teachers held about images which were in Turkish Science textbooks. $57.5 \%$ of female teachers and $54 \%$ of male teachers have stated that gender roles within images in Science textbooks have not been considered in the process of preparing them. This result concurs with similar studies related to Science textbooks and gender issues. Whiteley (1996a) found that most of the integrated Science textbooks used in Jamaican high schools exhibit a male bias. Whiteley (1996b) found in his study of physics textbooks that a gender balance was not present. Elgar (2004) found a gender imbalance in both text and illustrations in favor of males in Bruneian Science textbooks. UNESCO (2008) noted that gender bias in textbooks is hidden in plain sight and the stereotypes of boys and girls are a camouflage of gender stratification and roles. Beede et al. (2011) determined women are vastly underrepresented in STEM jobs in the United States.

Another significant indicator is career guidance within gender equity. $50.6 \%$ of female teachers and $42.5 \%$ of male teachers think career guidance has been ignored in the Turkish Science education system. Although most of these participants think it has been ignored, $21.9 \%$ of female and $22.9 \%$ of male teachers think career guidance was not ignored. It was noted that some jobs such as nursing, pre-school teaching were mentioned for girls and engineering, and mechanic workmanship were mentioned for boys. These stereotypes were still held by some Science teachers. OECD (2015a) through the PISA tests found that girls had higher expectations for their careers than boys. It also stated that $<5 \%$ of girls contemplated pursuing a career in engineering and computing. Hill et al. (2010) stated that stereotypes may lower girls' aspirations for engineering and science careers. OECD (2016) career expectations in PISA 2006 indicated that girls and disadvantaged students are less likely to expect to pursue a scientific career.

As it was mentioned, gender equity does not mean that both girls and boys are the same biologically. Therefore, this study 
sought to ask Science teachers about whether science teaching in schools strengthened gender inequity or not. It was seen that most of the female teachers $(40.3 \%)$ and male teachers (44.8\%) thought that science teaching in schools had been strengthening gender inequality. Within this context, teachers' attitudes toward gender, to include both their school and their class climate, the hidden curriculum, and the teachers' behaviors were significant indicators. This study asked these teachers about the rate of exposing gender inequity for both boys and girls. It was found that $37.9 \%$ of male teachers and $41.1 \%$ of female teachers thought boys and girls were not exposed at the same ratio. It was also seen that $24.7 \%$ of female and $25.3 \%$ of male teachers stated their views as "irresolute." It was really interesting that they were not able to give any response to this statement. Guzzetti and Williams (1996) in their study found that their study's teacher attempted to address boy dominance during studying in the laboratory within partnership and discussion by grouping by gender. They stated that this approach could be applied to girls studying exclusively together, and this may facilitate more efficient learning as well as them being more active in the learning process, but this limits students' access to other's thinking. EACEA P9 Eurydice (2010), education systems, therefore, play an important role in fostering equal chances for everyone and in combating stereotypes. Schools have a duty to provide all children with the opportunity to discover their own identity, strengths and interests regardless of traditional gender expectations.

PISA and TIMSS are significant international exams which give science educators opportunities to learn much more whether there is gender equity or not within science education. It was seen in PISA 2015 that $4^{\text {th }}$ grade girls' science scores average (503) was more than boys' (484) average. This is not a statistically meaningful difference between $4^{\text {th }}$ grade boys and girls (MEB, 2016). However, in this study, most of teachers gave similar responses. $38.4 \%$ of female and $55.1 \%$ of male teachers stated that gender roles were not an effective variable on students' success in science. Although $27.3 \%$ of female teachers stated that gender was effective on science achievement and $10.3 \%$ of male teachers stated they both agree and strongly agree on science achievement. It is notable that more male teachers than female teachers think gender roles were not an effective variable on science achievement.

School leavers are thought to be a big problem within education. We also know that Turkish students' science achievement level is under the OECD average (OECD, 2012; OECD, 2015b) and Turkish $7^{\text {th }}$ grade students' science scores average was 4.21 under 20 questions, in a national exam called SBS. In addition, the $8^{\text {th }}$ grade students' science national TEOG exam average was 54.2 under 100 (MEB, 2015b; MEB, 2016). It could be understood from these results that Turkish students are not very successful in science. Due to these reasons, it is important to learn Turkish female and male teachers' views on the dropout in middle schools within the scope of science course. A significant number of both female teachers (45.2\%) and male teachers (44.8\%) thought gender inequity affected the dropout rate. The EC (2011) noted gender equality was needed to promote participation of boys and that this should address gender-related inequalities which affected boys, such as early school leaving and literacy rates.

Repetition is a problem for students in schools. Science teachers and administrators have been facing repetition problems in Turkish secondary schools. Worrying was that most of the female teachers (38.4\%) answered "irresolute." In addition, $32.8 \%$ of them have stated that they disagreed (both strongly disagrees and disagree) with this statement. However, most of the male teachers $(42.5 \%)$ stated that they disagreed with the statement. These different results show male and female teachers hold different views on this statement. The reason for this difference could be attributed to cultural and traditional factors.

Most female teachers (20.5\% - strongly disagree; $26 \%$ - disagree) thought that there was no necessity to allocate more time to boys than girls. Most of the male teachers (18.4\% - strongly disagree; $27.6 \%$ - disagree) had the same view. Although $34.2 \%$ of female and $34.5 \%$ of male teachers stated no view on this statement. Hines (2007) argued there is no difference within general intelligence of males and females based on their gender. USAID (2008) note that if educators want to create learning opportunities which will enable all children to reach their full potential, they must know how stereotypes limit the opportunities for boys and girls.

\section{CONCLUSIONS}

It has been understood that most of the male and female teachers think that Turkish science education system has several indicators which have been enhancing gender inequity. This means gender equity has not been carried out for all students. It is aimed that there will be access to Science education for all students. If Turkey wants to reach this aim, there must be reforms in its science education as most of the teachers indicated no view on some statements. This may mean that these teachers did not have enough knowledge on these significant indicators. Due to these results, it is recommended that Science teachers have some courses concerning gender equity in the scope of in-service training and Science teacher candidates be trained around gender equity while they are at the university. In addition, the tools of the science curriculum such as Science textbooks, images, language and so on should be redesigned for gender equity as a significant number of the participants (17.5\% - strongly disagree; $27.5 \%$ - disagree) of the study think that there is no gender equity in education in Turkey. Almost half of the male teachers $(44.8 \%$ disagree and strongly disagree) did not think there was gender equity in Science education. While more than half of their female counterparts $(53.9 \%$ strongly disagree and disagree) did not think that there was gender equity in science education in Turkey. This negative view of gender equity is significant. As Science teachers are the ones who conduct science courses and 
if the aim is to give equal opportunities to all students, then Science teachers should hold positive views.

\section{REFERENCES}

Bazler, J. (1991). Are high school chemistry textbooks gender fair? Journal of Research in Science Teaching, 28(4), 353-362.

Beede, D., Julian, T., Langdon, D., McKittrick, G., Khan, B., \& Doms, M. (2011). Women in STEM: A Gender Gap to Innovation. Washington, DC: U.S. Department of Commerce, Economics and Statistics Administration.

Dimopoulos, K., Koulaidis, V., \& Sklaveniti, S. (2005). Towards a framework of socio-linguistic analysis of Science textbooks: The Greek case. Research in Science Education, 35, 173-195.

EACEA P9 Eurydice. (2010). Gender Differences in Educational Outcomes: Study on the Measures Taken and the Current Situation in Europe. Available from: http://www.eacea.ec.europa.eu/education/eurydice/ documents/thematic reports/120en.pdf. [Last accessed on 2017 Jun 19].

Elgar, A.G. (2004). Science textbooks for lower secondary schools in Brunei: İssues of gender equity. International Journal of Science Education, 26(7), 875-894.

Euproean Commission (EC). (2011). Strategy for equality between women and men 2010-2015. Luxembourg: Publications Office of the European Union.

Fraenkel, J.R., \& Wallen, N.E. (2011). How to Design and Evaluate Research in Education. $7^{\text {th }}$ ed. New York: The McGraw-Hill.

Good, J.J., Woodzicka, J.A., \& Wingfield, L.C. (2010). The effects of gender stereotypic and counter-stereotypic textbook images on Science performance. The Journal of Social Psychology, 150(2), 132-147.

Guzzetti, B.J., \& Williams, W.O. (1996). Gender, text, and discussion: Examining intellectual safety in the Science classroom. Journal of Research in Science Teaching, 33(1), 5-20.

Hill, C., Corbett, C., \& Rose, A. (2010). Why So Few? Women in Science, Technology, Engineering, and Mathematics. Washington: AAUW.

Hines, M. (2007). Do sex differences in cognition cause the shortage of women in Science? In: Ceci, S.J., \& Williams, W.M., (Eds.), Why Aren't More Women in Science? Washington, DC: American Psychological Association. p101-112.

Lee, J.F.K., \& Collins, P. (2009). Australian english-language textbooks: The gender issues. Gender and Education, 21(4), 353-370.

Magno, C., \& Silova, I. (2007). Teaching in transition; examining schoolbased inequities in central/south-eastern Europe and the former Soviet Union. International Journal of Educational Development, 27, 647-660.

MEB. (2000). İlköğretim Okulu fen Bilgisi Dersi Öğretim Programı. Ankara: Milli Eğitim Basımevi.

MEB. (2005). İlköğretim Fen ve Teknoloji Dersi Öğretim Programı. Ankara:
Milli Eğitim Basımevi.

MEB. (2015a). İlköğretim Kurumları Fen Bilimleri Dersi (3,4,5,6,7 ve 8. Sinıflar) Öğretim Programı. Ankara: Milli Eğitim Basımevi.

MEB. (2015b). TEOG, Derslerin Ortalama Puanları. Available from: http://www.mebk12.meb.gov.tr/meb iys dosyalar/35/04/714936/ dosyalar/2014_07/11101945_2014teoglleortalamalar\%C4\%B1.pdf. [Last accessed on 2017 Jun 19].

MEB. (2016). TIMSS 2015 Ulusal Matematik ve Fen Bilimleri ön Raporu 4. ve 8. Sinıflar. Ankara: MEB Yayınları.

MEB. (2017). İlköğretim ve Ortaöğretim Öğretim Programlarının Güncellenmesi. Erişim Adresi. Available from: https://www.ttkb. meb.gov.tr/www/ilkogretim-ve-ortaogretim-ogretim-programlarinin guncellenmesi/icerik/289.

OECD. (2012). Education at a Glance 2012. Available from: https://www. oecd.org/edu/EAG\%202012_e-book_EN_200912.pdf. [Last accessed on 2017 Jun 19].

OECD. (2015a). The ABC of Gender Equality in Education: Aptitude, Behaviour, Confidence, PISA. DOI: Org/10.1787/9789264229945-en.

OECD. (2015b). PISA 2015 Results in Focus. Available from: https://www. oecd.org/pisa/pisa-2015-results-in-focus.pdf. [Last accessed on 2017 Jun 19].

OECD. (2016). Equations and Inequalities: Making Mathematics Accessible to All, PISA. DOI: Org/10.1787/9789264258495-en.

Potter, E.F., \& Rosser, S.V. (1992). Factors in life science textbooks that may deter girls' interest in science. Journal of Research In Science Teaching 29(7), 669-686.

UNESCO. (2000). Gender Equality and Equity: A Summary Review of UNESCO's Accomplishments Since the Fourth World Conference on Women (Beijing 1995). Available from: http://www.unesdoc.unesco. org/images/0012/001211/121145e.pdf. [Last accessed on 2017 Jun 19].

UNESCO. (2008). Education for All by 2015: Will we Make it. Available from: http://www.unesdoc.unesco.org/images/0015/001547/154743e. pdf. [Last accessed on 2017 Jun 19].

USAID. (2008). Educatıon from a Gender Equality Perspectıve. Available from: http://www.ungei.org/resources/files/Education_from a Gender Equality_Perspective.pdf. [Last accessed on 2017 Jun 19].

Whiteley, P. (1996a). The 'gender fairness' of integrated Science textbooks used in Jamaican high schools. International Journal of Science Education, 18(8), 969-976.

Whiteley, P. (1996b). The gender balance of physics textbooks: Caribbean and British books, 1985-91. Physics Education, 31(3), 169-174.

Whiteley, P. (2007). The 'gender fairness' of integrated Science textbooks used in Jamaican high schools. International Journal of Science Education, 18(8), 969-976.

Zittleman, K., \& Sadker, D. (1996). Gender bias in teacher education texts new (and old) lessons. Journal of Teacher Education, 53(2), 168-180. 


\section{APPENDIX}

Dear Science teacher,

This study aims to determine and produce effective solutions on gender equity in the scope of Science education. Your feedback is important for us to reach the goals of the study. The questionnaire will be used in a scientific study, will not be published anywhere and will not be shared. Thank you for your contribution.

Sincerely,

\section{Dr. Şahin IDIN}

Science and STEM Educator

\section{Participant Details:}

Gender:

Women:

Men:

Age:

Educational Status: College:
Bachelor's Degree:

Doctoral Degree:
1-5:
6-10:

11-15:

College:

\section{İsmail DÖNMEZ}

Science Teacher

\begin{tabular}{|c|c|c|c|c|c|c|}
\hline Work Time: & 6-10: $\square$ & 11-15: $\square$ & 16-20: $\square$ & 1-25: $\square$ & \multicolumn{2}{|c|}{26 and above: } \\
\hline City: & 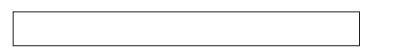 & & & & & \\
\hline Type Of School: & Middle School: $\square$ & College: $\square$ & Other: $\square$ & & & \\
\hline Items & & & $\begin{array}{l}\text { Strongly } \\
\text { Disagree }\end{array}$ & Irresolute & Agree & $\begin{array}{c}\text { Strongly } \\
\text { Agree }\end{array}$ \\
\hline
\end{tabular}

1. There is gender equity in our country.

2. There is gender equity in Science education in our country.

3. Our Science education policies supplied gender inequality.

4. Gender equity is guaranteed by the written law.

5. There are written laws for blocking the inequality in Science education.

6. Science curriculum has been prepared by considering gender equity.

7. Science textbook has been prepared by considering gender equity.

8. Images in the Science textbooks have been made by considering gender inequality.

9. The language of the Science lesson textbook is prepared by considering gender inequality.

10. Tools and equipment used in Science lessons are manufactured by considering gender equity.

11. An effective guidance prepared within Science education for students is carried out in terms of gender equity in schools.

12. School management and Science teachers are extremely effective in solving gender inequality in schools .

13. There is offical capacity of school management to provide gender inequality in schools.

14. A Career guidance for students is prepared by considering gender equity in Science education.

15. The effect of the hidden school curriculum has an impact in causes of gender inequalities (school climate, gender-based violence and harassment).

16. There is an influence of the hidden curriculum in the context of classroom Science lesson.

17. Science teachers get education for gender inequality in universities.

18. The cirruculum of teacher college has lessons for gender inequality.

19. Co-education increases the rate of gender inequality.

20. I believe that the rate of single-sex schools would reduce gender inequality.

21. The single-sex classes should be used to solve gender inequality in terms of Science lessons. 


\begin{tabular}{|c|c|c|c|c|c|c|}
\hline & Items & $\begin{array}{l}\text { Strongly } \\
\text { Disagree }\end{array}$ & Disagree & Irresolute & Agree & $\begin{array}{c}\text { Strongly } \\
\text { Agree }\end{array}$ \\
\hline 22. & $\begin{array}{l}\text { Science education given in schools, has been strengthening stereotype on } \\
\text { gender inequality. }\end{array}$ & & & & & \\
\hline 23. & $\begin{array}{l}\text { As a result of Science education, students tend to an employment based on } \\
\text { gender issues. }\end{array}$ & & & & & \\
\hline 24. & Boys and girls are exposed to gender inequality at the same ratio. & & & & & \\
\hline 25 . & Gender inequality has an effect on the scores which are obtained in exams. & & & & & \\
\hline 26. & $\begin{array}{l}\text { There is a contribution of gender inequality because of differences in the } \\
\text { dropout rate of girls and boys. }\end{array}$ & & & & & \\
\hline 27. & Gender inequality has an effect on repetition rate between boys and girls. & & & & & \\
\hline 28 & In and out of school, I consider the distinctive mark in gender character. & & & & & \\
\hline 29. & $\begin{array}{l}\text { Boys are more successful than girls in Science lessons, and classroom or } \\
\text { extracurricular, therefore, should be allocated more time for girls more than } \\
\text { boys. }\end{array}$ & & & & & \\
\hline 30. & $\begin{array}{l}\text { Girls are more successful in Science lessons, and classroom or extracurricular } \\
\text { therefore more time should be allocated for boys more than girls. }\end{array}$ & & & & & \\
\hline 31. & $\begin{array}{l}\text { Absence of positive attitude and experience to the disadvantage of the girls } \\
\text { must be solved by the parents and teachers by cooperating in and out school. }\end{array}$ & & & & & \\
\hline 32. & Gender equality must be a policy of the whole school. & & & & & \\
\hline 33. & $\begin{array}{l}\text { While the majority of boys tend to choose occupations in Science, } \\
\text { mathematics and technology and engineering practice, the low rate of } \\
\text { operating in this field. }\end{array}$ & & & & & \\
\hline 34. & $\begin{array}{l}\text { Gender inequality, between boys and girls in education, is increasing every } \\
\text { year. }\end{array}$ & & & & & \\
\hline 35. & $\begin{array}{l}\text { Racial, ethnic and socio-cultural influences leads to gender inequality in } \\
\text { Science education. }\end{array}$ & & & & & \\
\hline
\end{tabular}

